\title{
Yksivuotiset laidunkasvit luomutiloilla: kokemukset hyötykäyttöön neuvonnan ja tutkimuksen yhteishankkeessa
}

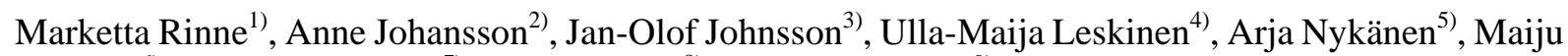
Pesonen ${ }^{6)}$, Pirkko Tuominen ${ }^{7}$, Ulla Turunen ${ }^{8)}$ ja Marja Suutarla ${ }^{9)}$

${ }^{1)}$ MTT Kotieläintuotannon tutkimus, Jokioinen, marketta.rinne@mtt.fi

${ }^{2)}$ ProAgria Länsi-Suomi, Pori, anne.johansson@proagria.fi

${ }^{3)}$ ProAgria Österbotten, Vaasa, jan-olf.johnsson@proagria.fi

${ }^{4)}$ ProAgria Etelä-Pohjanmaa, Seinäjoki, ulla-maija.leskinen@proagria.fi

${ }^{5)}$ ProAgria Etelä-Savo, Mikkeli, arja.nykanen@proagria.fi

${ }^{6)}$ MTT Kotieläintuotannon tutkimus, Ruukki, maiju.pesonen@mtt.fi

${ }^{7)}$ ProAgria Pohjois-Savo, Kuopio, pirkko.tuominen@proagria.fi

${ }^{8)}$ ProAgria Pohjois-Karjala, Joensuu, ulla.turunen@proagria.fi

${ }^{9}$ ProAgria Etelä-Suomi, Kouvola, marja.suutarla@proagria.fi

\section{Tiivistelmä}

Maa- ja metsätalousministeriön Laatuketjun rahoittamassa Luomuneuvonnan kehittämishankkeessa tehtiin kesällä 2013 maatilojen, ProAgrian ja MTT:n yhteistyönä havaintokokeita eri aiheista. Märehtijäryhmä valitsi aiheekseen yksivuotiset laitumet, jotka tarjoavat tiloille lisävaihtoehdon kesäkauden rehustukseen.

Neuvojat kartoittivat sopivia seurantaan mukaan lähteviä asiakastiloja ja mukaan saatiin 14 luomutilaa eri puolilta Suomea. Mukana oli laaja kirjo erilaisia yksivuotisia laidunkasveja. Näistä raiheinät ovat tyypillisiä nopeakasvuisia ja satoisia yksivuotisten nurmien kasvilajeja pääosin seoksina muiden kasvilajien kanssa. Useissa seoksissa oli mukana myös viljoja, jotka syötettiin laitumessa vihantana. Koska kyseessä olivat luomutilat, myös erilaiset palkokasvit kuuluivat tyypillisiin seoskasveihin. Käytettyjä yksivuotisia palkokasvilajeja olivat virnat, härkäpapu ja herne. Lisäksi puolessa kasvustoista mukana oli monivuotisia heiniä ja apiloita eli samalla perustettiin monivuotinen laidunnurmi.

Kasvustojen kehitystä seurattiin toistuvin näytteenotoin. Laidunkasvuston massan määrä saatiin selville kehikkomittauksin. Valion ARTTURI ${ }^{\circledR}$-analyysin avulla määritettiin kasvustojen ravitsemuksellinen laatu ja kivennäiskoostumus. Tyypillisesti laidunkasvustojen D-arvo (sulavuus eli energia-arvo) oli hyvin korkea sekä raakavalkuais- ja kaliumpitoisuudet suuria, mutta kuiva-ainepitoisuus matala. Kasvun edetessä ravitsemuksellinen laatu laski samoin kuin niittonurmissa, joten laidunnuksen ajoitukseen on kiinnitettävä huomiota. Neuvojat keräsivät lisäksi viljelijöiltä tiedot kasvustojen perustamisesta, perustelut yksivuotisten laidunkasvien käytölle ja kartoittivat kokemuksia laiduntamisesta ja lisäruokinnasta.

Luomuviljelijät kokivat yksivuotisten laidunkasvustojen käytöstä useita hyötyjä. Systemaattisesti kerättyjen näytteiden valossa kasvustojen potentiaali niin sadon laadun kuin määrän osalta on hyvä, vaikka vaihtelu eri kasvustojen välillä olikin suurta ja joissain tapauksissa rikkakasveja esiintyi runsaasti.

Asiasanat: laidun, luonnonmukainen tuotanto, nurmirehu, rehuanalyysi, rehuarvo, sulavuus

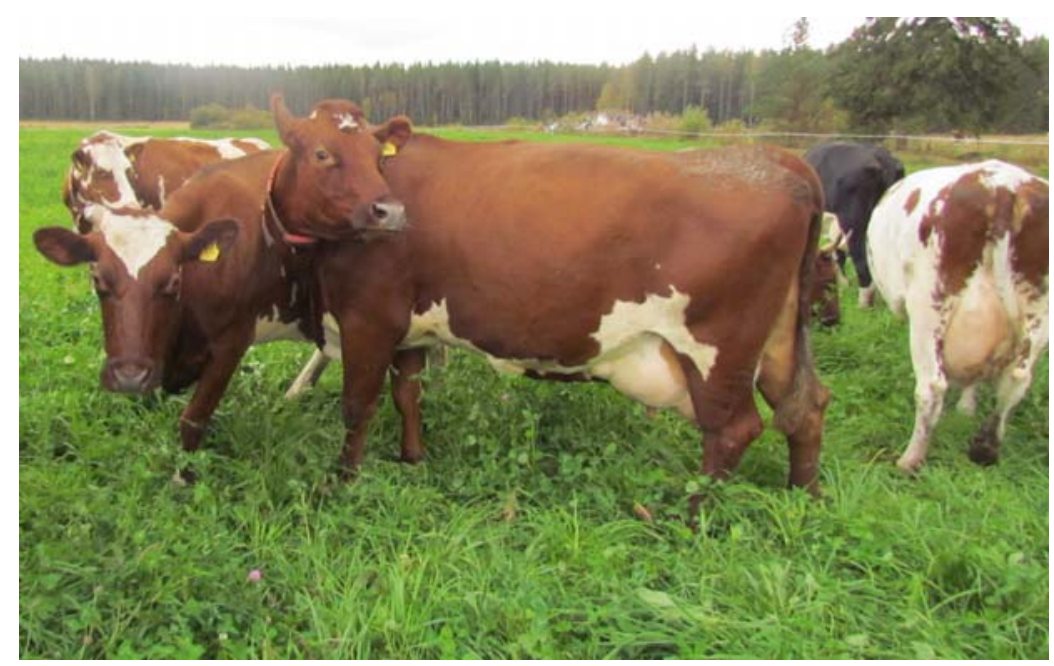

Kuva 1. Lehmät laiduntavat yksivuotista laidunta 18.9.2013. Kasvustoon on kylvetty kauraa, hernettä ja raiheinää ja siinä on monivuotinen nurmi alla (ruokonata, timotei, puna- ja valkoapila). Kuva: @ProAgria Ulla-Maija Leskinen. 


\section{Johdanto}

MMM:n Laatuketjun rahoittamassa Luomuneuvonnan kehittämishankkeessa (Lutune) tehtiin kesällä 2013 maatilojen, ProAgrian neuvojien ja MTT:n tutkijoiden yhteistyönä havaintokokeita eri aiheista. Märehtijäryhmä valitsi aiheekseen yksivuotiset laitumet, jotka tarjoavat tiloille yhden lisävaihtoehdon kesäkauden rehustukseen.

Laiduntaminen on vähentynyt selkeästi Suomessa viime vuosikymmeninä, mikä näkyy myös ProAgrian keräämistä rehunkäyttötilastoista. Luomutiloilla laiduntaminen kuitenkin kuuluu karjatilojen normaalikäytäntöihin jo luomusän̈ntöjen perusteella. Yksivuotiset laitumet tuovat tiettyjä etuja laidunnuksen järjestämiseen. Tässä hankkeessa halusimme selvittää millaisia kasvilajiseoksia luomutiloilla on käytössä, millaista rehua ne tuottavat ja millaisia kokemuksia viljelijöille yksivuotisten laidunten käytöstä on kertynyt.

\section{Aineisto ja menetelmät}

ProAgrian neuvojat kartoittivat sopivia seurantaan mukaan lähteviä asiakastiloja ja mukaan saatiin 14 luomutilaa eri puolilta Suomea. Kahdella tilalla seurannassa oli 2 eri kasvustoa, joten koko aineisto koostuu 16 eri laitumesta. Mukana oli laaja kirjo erilaisia yksivuotisia laidunkasveja. Näistä raiheinät ovat tyypillisiä nopeakasvuisia ja satoisia yksivuotisten nurmien kasvilajeja pääosin seoksina muiden kasvilajien kanssa. Useissa seoksissa oli mukana viljoja, jotka syötettiin laitumessa vihantana. Koska kyseessä olivat luomutilat, myös erilaiset palkokasvit kuuluivat tyypillisiin seoskasveihin. Käytettyjä yksivuotisia palkokasvilajeja olivat virnat, härkäpapu ja herne. Lisäksi puolessa kasvustoista mukana oli monivuotisia heiniä ja apiloita eli samalla perustettiin monivuotinen laidunnurmi. Yhteenveto kasvustoissa käytetyistä kasvilajeista on kerätty taulukkoon 1 ja seosten tarkempi koostumus taulukkoon 2.

Kasvustojen kehitystä seurattiin toistuvin näytteenotoin. Näyte kerättiin $1 \mathrm{~m}^{2}$ määräalalta käyttäen $0.25 \mathrm{~m}^{2}$ kehikkoa ja samalla mitattiin kasvuston korkeus. Punnitsemalla näytteen määrä saatiin selville kasvuston hehtaarimassa. Näytteen kasvilajikoostumus määritettiin näytteestä lajittelemalla (botaaninen analyysi) tai silmämääräisesti arvioiden. Näyte lähetettiin Valion ARTTURI ${ }^{\circledR}$-analyysiin (Artturi 2013), jossa määritettiin kasvustojen ravitsemuksellinen laatu ja kivennäiskoostumus. Neuvojat keräsivät lisäksi viljelijöiltä tiedot kasvustojen perustamisesta, perustelut yksivuotisten laidunkasvien käytölle ja kartoittivat kokemukset laiduntamisesta ja lisäruokinnasta.

Suurimmassa osassa kasvustoja seurattiin kasvustojen kehitystä toistuvin näytteenotoin ennen ensimmäistä laiduntamista. Viimeinen näytteenotto ajoittui tyypillisesti laidunnuksen aloitushetkeen. Joitain kasvustoja seurattiin eri laidunkierroissa, mutta tällöin otettiin vain yksi näyte laidunkiertoa kohti ja näyte ajoitettiin mahdollisimman lähelle laidunnuksen aloitusta.

Kyseessä ei ollut järjestetty koe kerranteineen vaan läpileikkaus luomutiloilla toteutuviin käytäntöihin. Tuloksia ei ole analysoitu tilastollisesti vaan kuvailtu aineistoa, raportoitu keskiarvoja hajontoineen ja esitetty kehityslinjoja kuvin.

Taulukko 1. Seurannassa olleiden yksivuotisten luomulaitumien (1-16) siemenseoksissa mukana olleet kasvilajit.

\begin{tabular}{|l|l|l|l|l|l|l|l|l|l|l|l|l|l|l|l|l|l|}
\hline & $\mathbf{1}$ & $\mathbf{2}$ & $\mathbf{3}$ & $\mathbf{4}$ & $\mathbf{5}$ & $\mathbf{6}$ & $\mathbf{7}$ & $\mathbf{8}$ & $\mathbf{9}$ & $\mathbf{1 0}$ & $\mathbf{1 1}$ & $\mathbf{1 2}$ & $\mathbf{1 3}$ & $\mathbf{1 4}$ & $\mathbf{1 5}$ & $\mathbf{1 6}$ & Yht. \\
\hline Raiheinät & $\mathrm{X}$ & & $\mathrm{X}$ & $\mathrm{X}$ & $\mathrm{X}$ & $\mathrm{X}$ & $\mathrm{X}$ & $\mathrm{X}$ & $\mathrm{X}$ & $\mathrm{X}$ & $\mathrm{X}$ & $\mathrm{X}$ & $\mathrm{X}$ & & $\mathrm{X}$ & $\mathrm{X}$ & 14 \\
\hline Kaura & & $\mathrm{X}$ & $\mathrm{X}$ & $\mathrm{X}$ & & & $\mathrm{X}$ & $\mathrm{X}$ & $\mathrm{X}$ & $\mathrm{X}$ & $\mathrm{X}$ & $\mathrm{X}$ & $\mathrm{X}$ & $\mathrm{X}$ & & $\mathrm{X}$ & 12 \\
\hline Virnat & & $\mathrm{X}$ & $\mathrm{X}$ & $\mathrm{X}$ & $\mathrm{X}$ & $\mathrm{X}$ & $\mathrm{X}$ & $\mathrm{X}$ & $\mathrm{X}$ & & & $\mathrm{X}$ & $\mathrm{X}$ & & & & 10 \\
\hline $\begin{array}{l}\text { Heinät (monivuoti- } \\
\text { set) }\end{array}$ & $\mathrm{X}$ & $\mathrm{X}$ & & & & & $\mathrm{X}$ & & & $\mathrm{X}$ & $\mathrm{X}$ & $\mathrm{X}$ & $\mathrm{X}$ & $\mathrm{X}$ & & & 8 \\
\hline Apilat & $\mathrm{X}$ & $\mathrm{X}$ & & & & & $\mathrm{X}$ & & & $\mathrm{X}$ & $\mathrm{X}$ & $\mathrm{X}$ & $\mathrm{X}$ & $\mathrm{X}$ & & & 8 \\
\hline Vihantaherne & $\mathrm{X}$ & $\mathrm{X}$ & & & & & & & & $\mathrm{X}$ & & $\mathrm{X}$ & $\mathrm{X}$ & $\mathrm{X}$ & & & 6 \\
\hline Ohra & & & $\mathrm{X}$ & & $\mathrm{X}$ & & & $\mathrm{X}$ & & & & & & & & & 3 \\
\hline Vehnä & & & & & & & & & & & & $\mathrm{X}$ & $\mathrm{X}$ & & & & 2 \\
\hline Syysruis & & & & & & $\mathrm{X}$ & & & & & & & & & & & 1 \\
\hline Vihantahärkäpapu & & & & & & & & & & & & & $\mathrm{X}$ & & & & 1 \\
\hline
\end{tabular}


Taulukko 2. Seurannassa olleiden yksivuotisten luomulaitumien (1-16) siemenseokset.

\begin{tabular}{|c|l|}
\hline & Siemenseoksissa käytetyt kasvilajit ja lajikkeet sekä siemenen käyttömäärä (kg/ha) \\
\hline 1 & $\begin{array}{l}\text { Timotei Grindstad 6, Koiranheinä Ambra 6, nurminata Kasper 6, alsikeapila Frida 3, valkoapila Sonja 3, englan- } \\
\text { ninraiheinä Riikka 15, vihantaherne 40 kg }\end{array}$ \\
\hline 2 & $\begin{array}{l}\text { Herne Arvika 70, Kaura Aslak 90, Virna n. } 20 \text { (juuressa monivuotinen nurmiseos: timotei 15, nurminata 10, } \\
\text { niittynurmikka 5, valkoapila 3) }\end{array}$ \\
\hline 3 & Kaura Roope 50, ohra Jyvä 50, rehuvirna Ebena 25, italianraiheinä Meroa 25 \\
\hline 4 & Kaura Roope 120, rehuvirna 20, italianraiheinä 5 \\
\hline 5 & Ohra Volmari 60, ruisvirna Hungvillosa 20, rehuvirna Ebena 20, italianraiheinä 20 \\
\hline 6 & Syysruis Iivo 80, rehuvirna Ebena 25, Italianraiheinä Meroa 25 \\
\hline 7 & $\begin{array}{l}\text { Rehuvirna Ebena 50, kaura Akseli 50, puna-apila Ynve 3, valkoapila Sonja 3, timotei Grindstad 12, nurminata } \\
\text { Kasper 3, englanninraiheinä 5, rainata Hygor 5 }\end{array}$ \\
\hline 8 & Rehuvirna Ebena 11, raiheinä 40, kaura 80, ohra 40 \\
\hline 9 & Kaura Roope 100, ruisvirna Savene 20, rehuvirna Ebena 20, italianraiheinä Meroa 20 \\
\hline 10 & $\begin{array}{l}\text { Kaura Veli 200, herne Kleopatra 60, ruokonata Kora 10, timotei Tenho 10, puna-apila Bjursele 5, valkoapila } \\
\text { Sonja 4, raiheinä Riikka 10 }\end{array}$ \\
\hline 11 & $\begin{array}{l}\text { Kaura Peppi 80, timotei Grindstad 15, nurminata Kasper 6, alsikeapila Frida 2, valkoapila Sonja 2, englannin- } \\
\text { raiheinä Riikka 10 }\end{array}$ \\
\hline 12 & $\begin{array}{l}\text { Rehuvirna Ebena 50, herne Florida 50, kaura Venla 80, kevätvehnä Anniina 80, valkoapila Huia1, alsike Frida 1, } \\
\text { persianapila Marco Polo 1, italianraiheinä Meroa 4.25, rainata Hykor 4.25, timotei Grindstad4.25, niittynurmik- } \\
\text { ka Balin 4.25 }\end{array}$ \\
\hline 13 & $\begin{array}{l}\text { Härkäpapu Fuego 20, rehuvirna Ebena 50, herne Florida 50, kaura Venla 80, kevätvehnä Anniina 80, alsike } \\
\text { Frida1, persianapila Marco Polo 1, italianraiheinä Meroa 4.25, rainata Hykor 4.25, timotei Grindstad 4.25, } \\
\text { niittynurmikka Balin 4.25 }\end{array}$ \\
\hline 14 & Kaura Akseli 200, rehuherne Florida 40, heinänsiemen Retu+laidunseos 20, valkoapila Nemuniai 3 \\
\hline 15 & Italianraiheinä Meroa 15, Westerwoldinraiheinä Lemnos 15 \\
\hline 16 & Italianraiheinä Turgo 31.5, kaura Veli 230 \\
\hline
\end{tabular}

\section{Tulokset ja tulosten tarkastelu}

Hankkeen viljelijöiden perustelut yksivuotisten laidunkasvustojen käyttöön on esitetty taulukossa 3. Viljelijöiden näkemykset yksivuotisten laidunkasvustojen hyödyistä ovat varsin samansuuntaisia kuin tutkimuksissa havaitut. Nissinen (1992) raportoi mittavasta koesarjasta Lapista, jossa selvitettiin tavanomaisesti viljeltyjen raiheinä- ja vihantaviljavoittoisten yksivuotisten laidunkasvustojen menestymistä. Yksivuotiset kasvustot tuottivat runsaasti massaa ja sadontuotto ajoittui keski- ja loppukesälle, jolloin monivuotisten laidunten tuotto hiipuu, ja jopa varsin myöhäiseen syksyyn, jolloin monivuotiset laitumet täytyy rauhoittaa laiduntamiselta talvehtimisen varmistamiseksi.

Eräs neuvoja esittikin hyvän kysymyksen: Miksi ei käyttäisi yksivuotisia laitumia? Joitain huolen aiheitakin voi esiintyä. Tutkimuksissa yksivuotisten laidunten taloudellista tulosta monivuotisiin laitumiin verrattuna rasittavat perustuskustannukset eli siemen ja työ, jotka monivuotisissa laitumissa jakautuvat usealle satovuodelle (Nissinen 1992, Tracy ym. 2010). Laidunrehun hintaan vaikuttaa keskeisesti sadon määrä ja yksivuotiset väistämättä menettävät monivuotisten nurmien alkukesän parhaan sadontuottoajan, kun maa on silloin monesti vielä paljaana. Toisaalta viljelyyn ja laidunten laadun ja määrän hallintaan sekä syyslaiduntamiseen liittyvät edut eivät yksinkertaisissa katetuottolaskelmissa tule huomioiduksi. Onnistuessaan yksivuotisilla kasvustoilla on suuri sadontuotantopotentiaali ja toimiessaan pitkäikäisten laidunten uudistajina lisäävät välillisesti myös niiden satoa.

Taulukkoon 4 on koottu tulokset laidunkasvustoista. Jos kasvustosta on otettu useampia näytteitä ennen laidunnusta, tähän tarkasteluun on otettu mukaan vain viimeisen näytteen tiedot eli se pyrkii kuvaamaan tilannetta siinä vaiheessa kun laidun on otettu syöttöön. Kuvassa 3 on puolestaan tarkasteltu kasvustojen kehitystä kasvun edetessä ja viimeinen havainto edustaa syöttöön tullutta kasvustoa. 
Taulukko 3. Hankkeen luomuviljelijöiden perusteluja yksivuotisten laidunkasvustojen käyttöön.

\begin{tabular}{cc}
\hline Perustelu yksivuotisen laitumen sisällyttämiseen laidunviljelykiertoon & lkm \\
\hline - Saadaan ajoitettua laidunnettavaa kasvustoa keski- ja loppukesään, kun monivuotisten laidunten & 4 \\
- Sadontuottokyky laskee & 3 \\
- Tadaan luomutilan laidunviljelykiertoon apilaton vuosi & 2 \\
- Pystytään torjumaan kestorikkakasveja laidunlohna voidaan laiduntaa & 2 \\
- Saadaan suurempi sato kuin monivuotisesta laitumesta & 2 \\
- Estetään montavivuotisten laitumien tallautuminen syksyllä & 2 \\
- Voidaan korjata säilörehuksi, jos laidunta on riittävästi & 2 \\
- Tarjoaa ravintoa luonnon eläimille (kyyhkyset ja kurjet) & 1 \\
- Haää laidunkasvilajien määrää & 1 \\
- Parantan luomutilalle apilatonta säilörehua / laidunta syötettäväksi rakennetta & 1 \\
- Mahdollistaa nurmen perustamisen kuivanakin kesänä & 1 \\
- Typpilannoitusvaikutus, kun mukana palkokasveja & 1 \\
\hline
\end{tabular}

Vaihtelu laidunlohkojen kasvimassan määrässä oli erittäin suurta. Myös lohkojen sisällä vaihtelu oli erittäin suurta, mikä vaikeuttaa luotettavien mittausten tekemistä. Joidenkin lohkojen erittäin suuret kasvustomassat kuvaavat yksivuotisten laidunten suurta potentiaalia. Toisaalta joillain lohkoilla sekä kuivuus että märkyys näyttivät vaivaavan kasveja ja vaikuttivat nurmen tiheyteen huonon itämisen vuoksi. Joillain lohkoilla erityisen hyvin kasvoivat rikat. Neuvojat kokivat kasvustojen systemaattisen seurannan kehikkonäytteiden avulla hyödylliseksi työkaluksi, jota kannattaa jatkaa myös osana normaalia asiakastyötä.

Taulukko 4. Yksivuotisten laidunkasvustojen kuvailu kasvustojen tullessa syöttöön (n=23).

\begin{tabular}{|c|c|c|c|c|c|c|}
\hline & \multirow{2}{*}{$\begin{array}{l}\text { Keski- } \\
\text { arvo }\end{array}$} & \multirow{2}{*}{$\begin{array}{l}\text { Keski- } \\
\text { hajonta }\end{array}$} & \multirow{2}{*}{ Minimi } & \multirow{2}{*}{ Maksimi } & \multicolumn{2}{|c|}{ Vertailurehut } \\
\hline & & & & & Laidun $^{1)}$ & Säilörehu $^{2)}$ \\
\hline Tuoremassa, kg/ha & 21125 & 17935.7 & 1800 & 82240 & & \\
\hline Kuiva-ainemassa, kg/ha & 3555 & 3613.0 & 365 & 14639 & & \\
\hline Kasvuston korkeus, cm & 56 & 23.7 & 15 & 106 & & \\
\hline Palkokasvien osuus, \% & 34 & 21.3 & 0 & 68 & & \\
\hline Kuiva-aine (ka), g/kg & 161 & 32.4 & 116 & 254 & 200 & 374 \\
\hline \multicolumn{7}{|l|}{ Kuiva-aineessa, g/kg ka } \\
\hline Tuhka & 89 & 14.4 & 57 & 108 & 100 & \\
\hline Raakavalkuainen & 182 & 41.0 & 120 & 278 & 180 & 128 \\
\hline Sokeri & 86 & 40.9 & 30 & 161 & 125 & 76 \\
\hline Kuitu (NDF) & 483 & 47.5 & 386 & 568 & 550 & 517 \\
\hline Sulamaton kuitu (iNDF) & 78 & 30.7 & 45 & 152 & 48 & 95 \\
\hline D-arvo & 679 & 31.5 & 607 & 719 & 705 & 655 \\
\hline \multicolumn{7}{|l|}{ Rehuarvot $^{3)}$} \\
\hline ME, MJ/kg ka & 10.8 & 0.47 & 9.8 & 11.4 & 11.4 & \\
\hline OIV, g/kg ka & 91 & 8.0 & 78 & 108 & 95 & \\
\hline PVT, g/kg ka & 49 & 32.6 & -4 & 125 & 41 & \\
\hline \multicolumn{7}{|c|}{ Kivennäispitoisuudet, g/kg ka } \\
\hline Kalsium (Ca) & 5.5 & 2.78 & 2.0 & 13.2 & 3.8 & 7.2 \\
\hline Fosfori (P) & 4.0 & 0.73 & 2.5 & 5.4 & 3.5 & 2.6 \\
\hline Kalium (K) & 33.8 & 8.30 & 11.4 & 45.6 & 31 & 21.6 \\
\hline
\end{tabular}

${ }^{1)}$ Vertailutietona Rehutaulukoiden (MTT 2013) monivuotinen heinäkasvilaidun (rehukoodi 06001)

${ }^{2)}$ Vertailutietona ARTTURI ${ }^{\circledR}-$ rehuanalyysin luomuksi kirjatut säilörehunäytteet vuosilta 2010-2012 (n=1480)

${ }^{3)} \mathrm{ME}=$ muuntokelpoinen energia, OIV=ohutsuolesta imeytyvä valkuainen ja PVT=pötsin valkuaistase 
Taulukkoon 4 on otettu vertailutiedoksi Rehutaulukoiden laidun (näyte 06001) ja keskiarvo vuosina 20102012 luomuksi kirjatuista säilörehunäytteistä, jotka on analysoitu ARTTURI ${ }^{\circledR}-$ rehuanalyysillä. Laidunkasvustot olivat tyypillisesti hyvin tuoreita, sillä niiden keskimääräinen kuiva-ainepitoisuus oli vain 161 g/kg ka. Suurta eroa säilörehuihin selittää erityisesti korjuutekniikka eli säilörehua varten nurmea tyypillisesti esikuivataan ennen säilöntää. Toisaalta yksivuotisten laidunten kasvilajivalikoima vaikuttaa osaltaan kuiva-ainepitoisuuteen. Jos yksivuotisista kasvustoista tehdään säilörehua tilanteessa jossa laidunrehulle ei ole tarvetta, matala kuiva-ainepitoisuus on otettava rehunteossa huomioon. Jos kasvustoja ei saada kunnolla esikuivattua, runsas puristenesteen erittyminen säilörehusta on odotettavissa.

Toinen kuiva-ainepitoisuutta nostava tekijä on se, että säilörehuntekotilanteessa kasvustot korjataan tyypillisesti jonkun verran myöhäisemmässä kehitysvaiheessa kuin laitumena syötettäessä. Palkokasvipitoisten kokoviljasäilörehujenkaan kuiva-ainepitoisuus ei silti välttämättä ole kovin korkea. PohjoisPohjanmaalla v. 2012 kerätyssä aineistossa, jossa hernettä ja härkäpapua viljeltiin seoksina viljojen kanssa ja kasvustot korjattiin syyskesällä 3 eri kehitysvaiheessa, kasvustojen keksimääräinen kuiva-ainepitoisuus oli noin 200 g/kg ja D-arvo 640 g/kg ka (Kuoppala ym. 2014).

Rehuarvoiltaan laidunkasvustot olivat vain hieman matalampia kuin vertailuarvona käytetyn Rehutaulukoiden (MTT 2013) laitumen eli eläinten ravintoaineiden tarpeet tulevat tyypillisesti hyvin tyydytetyiksi. Kun kasvustojen maittavuuskin oli viljelijäkokemusten perusteella hyvä, eivät näkemykset kasvustojen hyvästä tuotantovaikutuksesta yllätä. Kasvun edetessä ravitsemuksellinen laatu laski nopeasti (kuva 3), joten laidunnuksen ajoitukseen on kiinnitettävä huomiota. Keskimääräinen D-arvon lasku oli $4.2 \mathrm{~g}$ päivässä, mikä on samaa luokkaa kuin heinäkasveihin perustuvissa säilörehunurmissa (Rinne ym. 2010a).

Kohtuullisen korkea raakavalkuaispitoisuus ja sen seurauksena korkea pötsin valkuaistase (PVT) kertovat siitä, että maan typpivarat ovat olleet hyviä ja/tai kasvustossa on runsaasti palkokasveja. Palkokasvien sisällyttäminen seoksiin on luomutilojen luonteva vaihtoehto ja monipuolistaa seosta vähentäen typpilannoitustarvetta myös tavanomaisilla tiloilla. Useimmat lohkot olivat olleet pitkäaikaisesti laidunkäytössä ja 12 lohkolle oli kasvustojen perustamisen yhteydessä annettu karjanlantaa. Typen hyväksikäytön kannalta raakavalkuaispitoisuus olisi saanut olla matalampi. Märehtijän typen tarvetta voi parhaiten arvioida koko rehuannoksen PVT-pitoisuuden avulla, joka lypsylehmillä saa olla 0 (Rehutaulukot 2013).

Lohkojen hyvä ravinnetila näkyi myös näytteiden kivennäisainepitoisuuksissa, erityisesti korkeahkoissa (keskimäärin $33.8 \mathrm{~g} / \mathrm{kg}$ ka) kaliumpitoisuuksissa, jotka olivat huomattavasti korkeampia kuin säilörehuissa (21.6 g/kg ka) mutta samaa tasoa kuin Rehutaulukoiden (2013) laitumessa (31 g/kg ka). Korkea kaliumpitoisuus voi häiritä magnesiumin imeytymistä ja altistaa laidunhalvaukselle, mutta keskimääräinen pitoisuus ei tässä aineistossa vielä ole hälyttävän korkea. Tiloilla ei myöskään havaittu laidunhalvauksia. Magnesiumpitoisen laidunkivennäisen käyttö lehmille on perusteltua, jos kaliumpitoisuudet rehuissa ovat korkeita.

Kuuselan ym. (2001, 2004) yksivuotisissa palkokasvipitoisissa luomulaitumissa ravitsemuksellinen laatu oli kohtuullinen ja kasvustot vahvistivat erityisesti syyskesän laidunnusmahdollisuuksia. Ruisvirna osoittautui rehuvirnaa kestävämmäksi laidunkasviksi. Apilaseokset tuottivat suuremman kuivaainesadon kuin virnapohjaiset, mutta kasvustojen maidontuotantovaikutuksessa ei ollut eroja. On myös muistettava että apiloiden laiduntamiseen liittyvä puhaltuminen voi aiheuttaa ongelmia myös yksivuotisissa laitumissa, mutta esim. virnat eivät aiheuta puhaltumista (Kuusela ym. 2004).
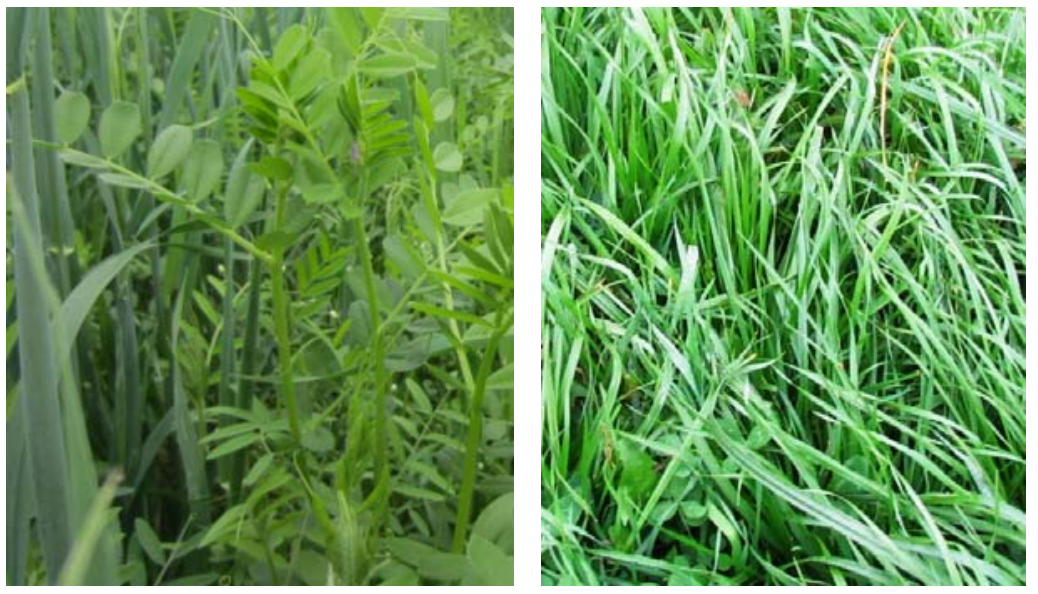

Kuva 2. Kaura- ja rehuvirnavaltainen kasvusto (vasemmalla, kuvattu 8.7.2013; @ProAgria Ulla Turunen) ja raiheinävaltainen kasvusto (oikealla, kuvattu 19.9.2013; @ProAgria Ulla-Maija Leskinen). 

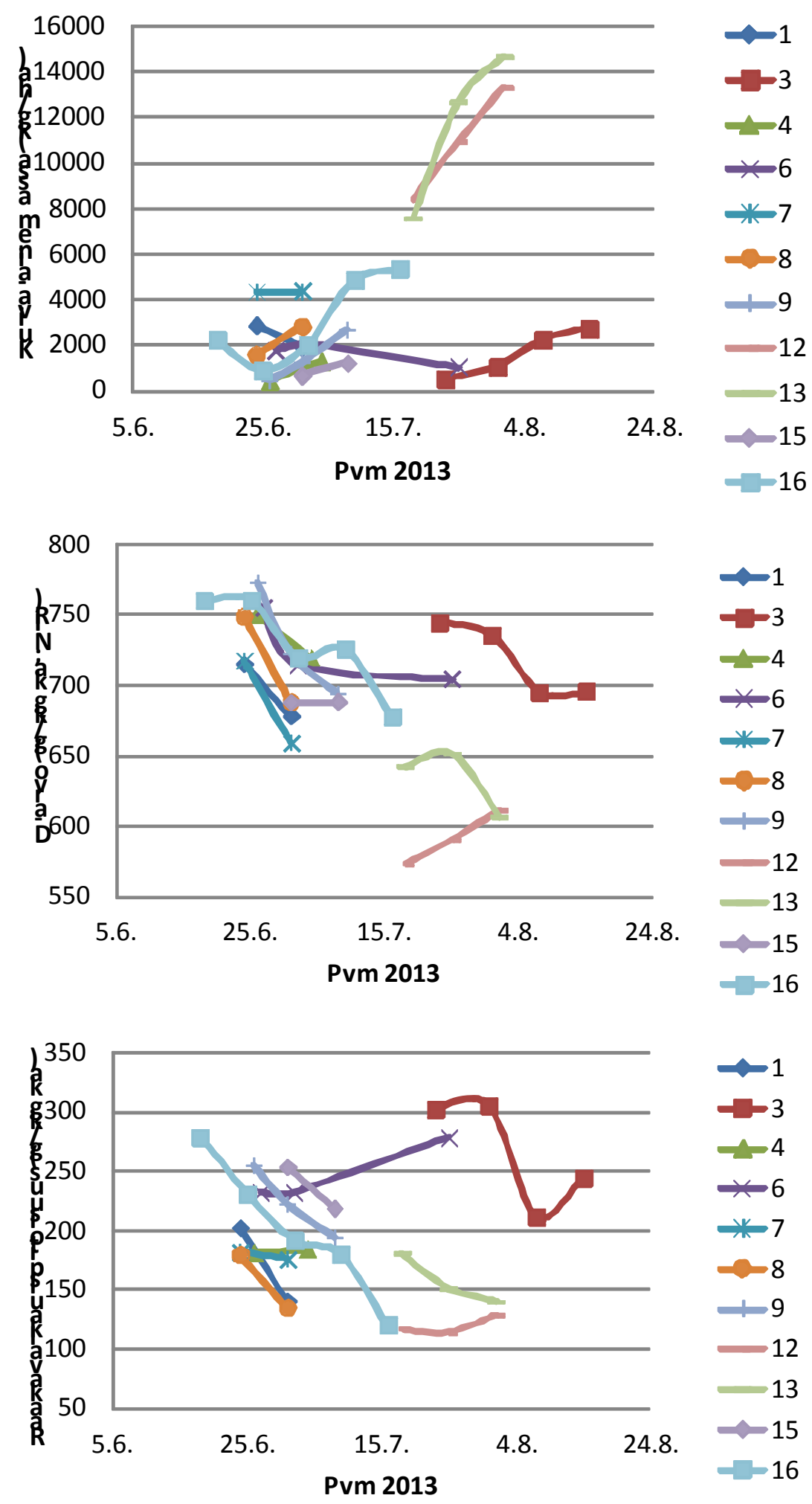

Kuva 3. Ensimmäisen laidunkierron kasvustojen kuiva-ainemassan (a), D-arvon (b) ja raakavalkuaispitoisuuden (c) kehitys kasvun edetessä. Jokaisen kasvuston eri aikoina otetut näytteet on yhdistetty viivalla. Kasvusto on tyypillisesti laidunnettu viimeisen näytteenoton jälkeen. 
Kuudella yksivuotisella laitumella seurattiin kasvustoja eri laidunkierroilla. Laidunnuskertoja oli joko 2 (4 lohkoa) tai 3 (2 lohkoa). Kuvan 4 perusteella selkeää suuntausta eri laidunkiertojen välillä ei havaittu rehun laadussa (D-arvo, raakavalkuaispitoisuus) eikä kuiva-ainemassassa. Vaihtelevia tekijöitä kasvustojen välillä oli useita, joten on vaikea arvioida yksittäisten tekijöiden (esim. kylvöaika, kasvilajikoostumus, laidunnusten ajoitus, paikalliset kasvuolosuhteet ym.) vaikutusta eri laidunkierroista tehtyihin havaintoihin.
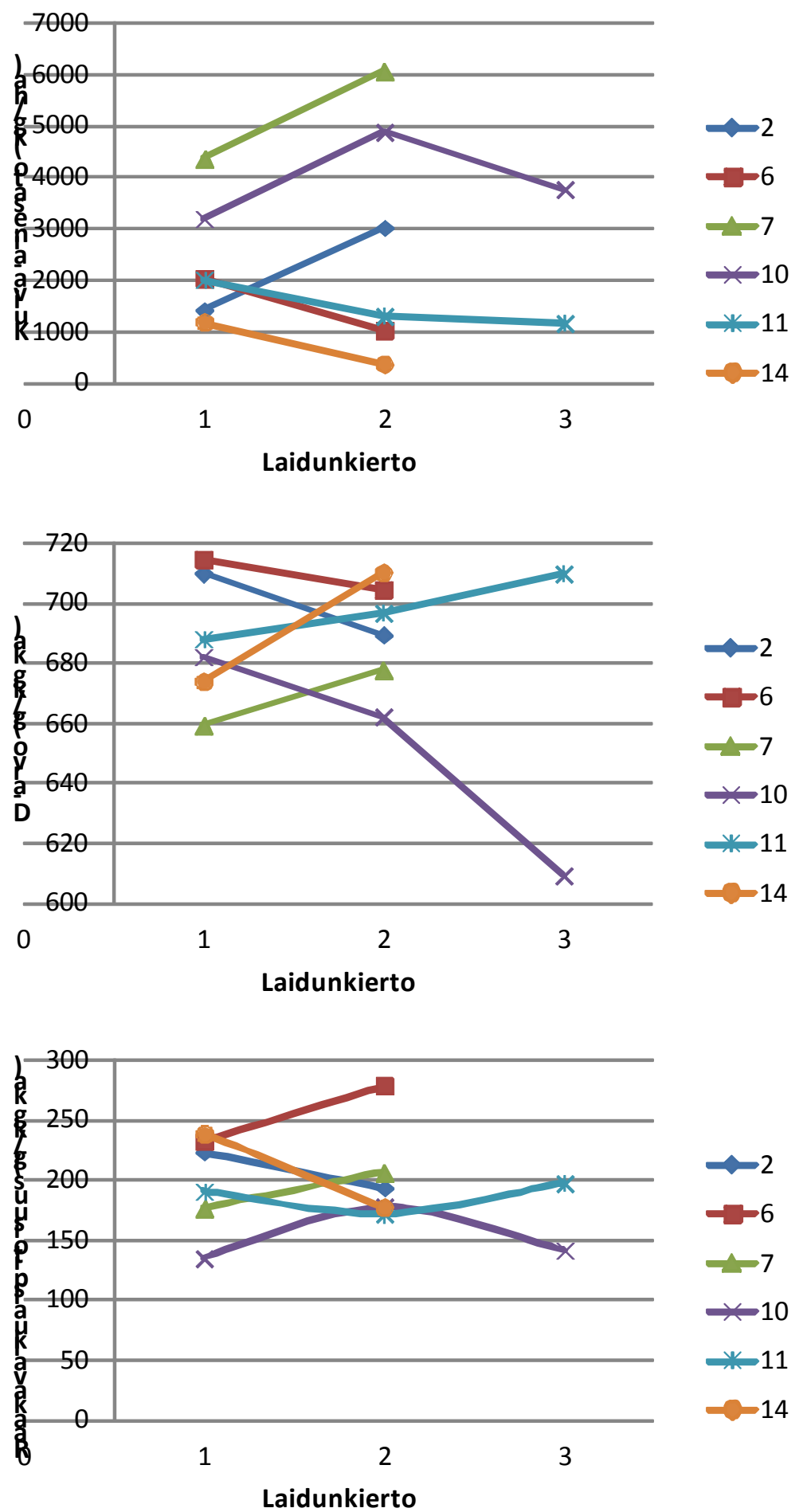

Kuva 4. Kuiva-ainemassa, D-arvo ja raakavalkuaispitoisuus eri laidunkierroilla. Samalta lohkolta otetut näytteet on yhdistetty viivalla. Kasvustot on tyypillisesti laidunnettu näytteenoton jälkeen. 


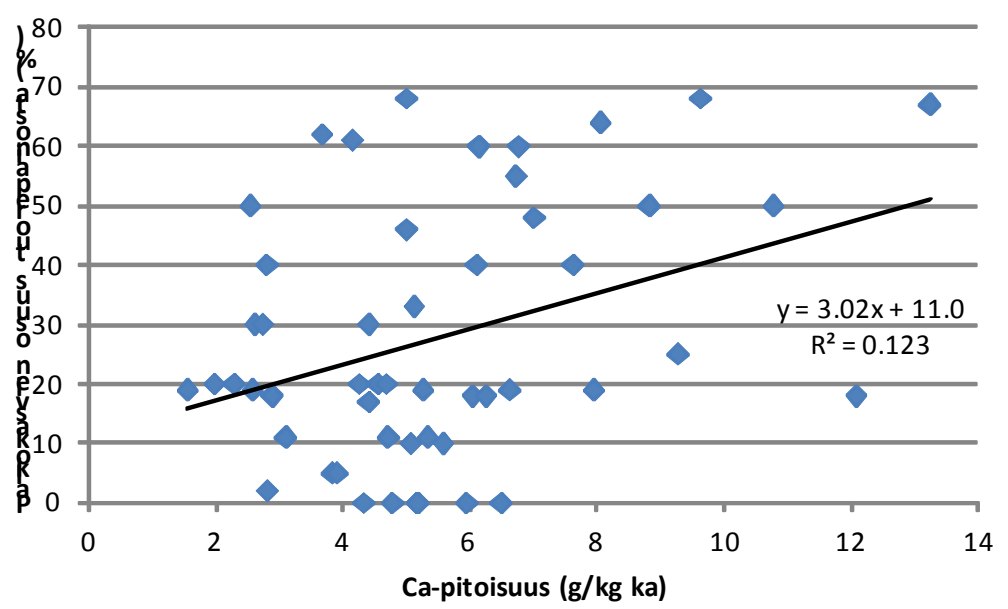

Kuva 5. Yksivuotisten laidunkasvustojen kalsiumpitoisuuden ja palkokasvien osuuden välinen yhteys oli heikko.

Palkokasvien kalsiumpitoisuus on selvästi korkeampi kuin heinäkasvien. Nurmiheinien ja puna-apilan seoskasvuston apilapitoisuus voidaan kohtuullisella tarkkuudella ennustaa näytteen kalsiumpitoisuudesta (Rinne ym. 2010b). Tässä aineistossa näytteiden kalsiumpitoisuuden ja palkokasvien osuuden välinen yhteys oli heikko (kuva 5). Osaltaan tätä selittää se, että virnojen, herneen ja härkäpavun kalsiumpitoisuus on apiloita pienempi (MTT 2013).

Selkeä peruste yksivuotisten laidunten käytölle on kestorikkakasvien, erityisesti juolavehnän, torjunta alkukesän kesannolla. Toisaalta yksivuotiset rikkakasvit, erityisesti jauhosavikka ja pillike, voivat vallata ensimmäisen laidunkierron kasvuston. Tällöin kärsivät niin sadon määrä kuin maittavuus. Rikkakasvit olivat joissain kasvustoissa merkittävä ongelma. Keskimäärin rikkojen osuus oli $13 \%$ (n=44, keskihajonta 12.6) vaihdellen 0:sta 49 prosenttiin. Mahdollisesti myöhäisempi kylvö ja kasvualustan muokkaus useampaan kertaan voisivat olla apuna niin yksi- kuin monivuotistenkin rikkojen hallinnassa, mutta toisaalta myöhäisempi kylvö lyhentää laidunnusaikaa ja pienentää kesän satoa. Puhdistusniitot toimivat melko hyvin yksivuotisten rikkakasvien hallinnassa ja yleensä rikkakasvien osuus kesän myöhemmissä laidunkierroissa on pieni (Nissinen 1992).

Muiden kuin kylvettyjen kasvilajien esiintyminen nurmissa ei itseisarvoisesti ole ongelma ja erityisesti luomutuotannossa tietty määrä rikkakasveja on syytä hyväksyä. Esimerkiksi voikukka ei Rahkosen ja Juutisen (2012) mukaan vaikuttanut merkittävästi nurmisäilörehun ravitsemukselliseen tai säilönnälliseen laatuun, tosin sadon määrään liittyviä vaikutuksia ei selvitetty. Luomuviljelijät vaikuttavat viljelijäkyselyn perusteella myös suhtautuvan rikkoihin sallivammin kuin tavanomaiset viljelijät (Pakarinen ym. 2012). Monet kylvämättömät kasvilajit kuitenkin vaikuttavat haitallisesti sadon määrään tai maittavuuteen ja voivat äärimmillään olla myrkyllisiä eläimille. Rikkakasvien hallinnassa auttaa se, että seoksessa on mukana nopeasti kehittyviä kasveja, jotka varjostavat rikkoja. Viljat orastuvat nopeasti ja tuottavat ensimmäiseen satoon massaa. Niiden alla hitaampikasvuiset mutta paremman jälkikasvun omaavat lajit kuten raiheinä valtaavat kasvua ensimmäisen syötön jälkeen (Nissinen 1992).

Yksivuotisia laitumia käytettiin yleisesti monivuotisten nurmien perustamiseen, sillä puolessa tämän seurannan siemenseoksista oli mukana monivuotisia heiniä ja apiloita. Laidunkasvustojen käyttö nurmen perustamisessa vähentää suojakasvien varjostusta ja edistää siten monivuotisen nurmen oraiden kehitystä, mutta toisaalta erityisesti märkinä vuosina uusi nurmi voi kärsiä tallausvaurioita. Monivuotisten laidunkasvien siemenmäärän suurentaminen säilörehunurmiin verrattuna voi auttaa perustettavan laidunnurmen aukkoisuuden vähentämisessä ja tiheän kasvuston perustamisessa.

\section{Johtopäätökset}

Luomuviljelijät kokivat yksivuotisten laidunkasvustojen käytöstä useita hyötyjä. Systemaattisesti kerättyjen näytteiden valossa kasvustojen potentiaali niin sadon laadun kuin määrän osalta on hyvä, vaikka vaihtelu eri kasvustojen välillä olikin suurta ja joissain tapauksissa rikkakasveja esiintyi runsaasti. Neuvojat kokivat hankkeessa käytetyt menetelmät kasvustojen seurannasta hyödyllisiksi. Tulosten prosessointia jatketaan seurantaan osallistuneiden viljelijöiden, neuvojien ja tutkijoiden yhteisellä työpajalla kevättalvella 2014. 


\section{Kiitokset}

Lämpimät kiitokset mukana olleille tiloille siitä että saimme seurata kasvustojanne ja jakaa kokemuksenne sekä Maa- ja metsätalousministeriölle hankkeen rahoituksesta.

\section{Kirjallisuus}

Artturi. 2013. ARTTURI $®$-verkkopalvelu. Saatavilla: $w$ ww.mtt.fi/artturi.

Kuoppala, K., Huuskonen, A., Saarinen, E. \& Rinne, M. 2014. Palkokasvi parantaa kokoviljasäilörehun rehuarvoa. Maataloustieteen Päivät 2014. www.smts.fi.

Kuusela, E.. Khalili, H. \& Nykänen-Kurki, P. 2004. Fertilisation, seed mixtures and supplementary feeding for annual legume-grass-cereal pastures in organic milk production systems. Livestock production Science 85: 113-127.

Kuusela, E., Sormunen-Cristian, R. \& Nykänen-Kurki, P. 2001. Yksivuotisten palkokasvien laiduntaminen. Suomen nurmiyhdistyksen julkaisu nro 14: 53-60.

MTT. 2013. Rehutaulukot ja ruokintasuositukset -verkkopalvelu. Saatavilla: www.mtt.fi/rehutaulukot.

Nissinen, O. 1992. Yksivuotisten tuorerehukasvien soveltuminen laidun- ja niittoruokintaan Pohjois-Suomessa. Maatalouden tutkimuskeskus. Tiedote 4/92. 45 p.

Nissinen, O. 2004. Vihantarehut suojaavat uutta nurmea. Koetoiminta ja käytäntö 61: 1(15.3.2004).

Pakarinen, K., Hyrkäs, M. \& Juutinen, E. 2012. Weed management of grassland and harmful effects of weeds in swards - on-farm experiences. In: Proceedings of the XVI International Silage Conference. Hämeenlinna, Finland, 2-4 July 2012 / Edited by K. Kuoppala, M. Rinne and A. Vanhatalo. MTT Agrifood Research Finland, University of Helsinki. p. 186-187. Available at: www.mtt.fi/isc.

Rahkonen, T. \& Juutinen, E. 2012. Voikukan vaikutus säilörehun säilöntälaatuun ja rehuarvoihin. Maataloustieteen Päivät 2012. Saatavilla: http://www.smts.fi/Nurmet/Rahkonen_Voikukan\%20vaikutus.pdf.

Rinne, M, Nykänen, A., Kemppainen, J., Nyholm, L. \& Nousiainen, J. 2010. Proportion of red clover in forage can be estimated based on calcium concentration. Proc. 1st Nordic Feed Science Conference, Uppsala, Sweden 23-24 June 2010. Swedish University of Agricultural Sciences, Dept. Animal Nutrition and Management, Report 274, pp. 5-9. Available in Internet at: https://arbetsplats.slu.se/sites/huv/Delade\%20dokument/NFSC_Proceedings_100617.pdf.

Rinne, M., Pitkänen, T., Nyholm, L., Nousiainen, J. \& Huhtanen, P. 2010. Alkukesän nurmikasvuston sulavuuden ja sadon määrän mallit nurmirehuntuotannon hallintaan. Maataloustieteen Päivät 2010. Saatavilla: www.smts.fi/jul2010/poste2010/136.pdf

Tracy, B.F., Maughan, M., Post, N. \& Faulkner, D.B. 2010. Integrating annual and perennial warm-season grasses in a temperate grazing system. Crop Science 50: 2171-2177. 